\title{
Financeirização de esquerda? \\ Frutos inesperados no Brasil do século XXI
}

Roberto Grün

É maio de 2007. A economia brasileira parece começar um novo ciclo de crescimento. Depois de quase duas décadas consideradas de estagnação econômica, a notícia entusiasma a imprensa e os políticos. Segundo alguns, o novo período alvissareiro teria sido deflagrado pela conjuntura internacional, em especial pelo crescimento da China, grande compradora das commodities brasileiras. Outros atribuem o papel central à "lição de casa benfeita" pelo atual governo que teria, ou não, aprofundado a política econômica de seu predecessor e rival. Para os partidários da primeira versão, o atual presidente e sua equipe simplesmente copiaram a lição de FHC, mas sem inspiração e de maneira malcuidada. Para os segundos, há inflexões tanto na indução microeconômica quanto na política econômica e monetária propriamente dita. Obviamente, os primeiros atribuem a boa situação a seus feitos passados e os últimos às suas realizaçōes presentes. O debate econômico é assim eivado de preocupações diretas ou sensibilidades partidárias e por habitus em conflito. Daí ser pouco provável que emerja algum consenso sobre as causas da situação favorável. Mas talvez valha a pena atentar para algumas peculiaridades estruturais da configuração que a economia e a sociedade brasileiras desenvolveram nos últimos anos para que tenhamos mais claras as suas possíveis fontes de dinamização e de impasse.

Numa primeira observação, percebe-se que a maior parte das notícias que conotam as boas novas diz respeito a assuntos que refletem a mudança 
de atitude dos mercados financeiros em relação ao Brasil: queda do "risco Brasil", valorização do real frente ao dólar norte-americano, quedas discretas mas constantes das taxas básicas de juros, investimentos maciços de fundos de private equities na agroindústria canavieira e balanço de pagamentos com o exterior superavitário. Não é assim por acaso que o setor menos afetado pelo otimismo seja o dos empresários industriais (cf. CNI, 2007). Em seguida, exumemos duas notícias dos jornais de maio de 2007: na primeira delas, Armínio Fraga e Luís Fernando Figueiredo, exemplos dos mais típicos desses novos financistas que surgiram no panorama econômico da década de 1990, abrem caminho para mais uma inovação financeira: o alongamento de prazos de carência para os fundos de investimentos, permitindo aos seus gestores o estabelecimento de estratégias mais amplas. E enquanto eles tomam a dianteira, os grandes bancos adotam uma postura cautelosa, esperando os resultados da "ousadia", para depois avaliar a conveniência de adotá-la (cf. Pavini, 2007, 17 maio). Na segunda notícia, mais notada, os principais jornais diários do país dão espaço a um "desabafo" de Lula, no qual ele lembra ao mesmo tempo as dificuldades que enfrentou para se aproximar da Bovespa e também o desenvolvimento dessa entidade durante o seu governo (cf. Damé, 2007, 18 maio; Dianni, 2007, 18 maio; Veríssimo, 2007, 17 maio).

Durante os governos de FHC, a Bovespa viveu uma fase "anêmica", em que parecia fadada a desaparecer, uma vez que os seus principais clientes, com a notável e obrigatória exceção dos fundos de pensão, pareciam desertála, em prol de suas homólogas mais "eficientes" de Nova York e Londres (cf. Ciarelli e Farid, 2002, 25 fev.). No primeiro período do governo de Lula, depois de um compromisso explícito do candidato com a entidade, essa tendência se inverteu (cf. Murphy, 2002, $1^{\circ}$ set.; Ripardo, 2002c, $1^{\circ}$ out.). No início do seu segundo termo, ela apresenta um crescimento expressivo do volume de negócios (cf. Veríssimo, 2007, 17 maio).

Finalmente, no começo de junho de 2007, a inversão parecia total, pois a Bovespa passa a ser apontada como potencial centralizadora dos negócios bursáteis de toda a América Latina (cf. Barbieri, 2007, 4 jun.). Num primeiro olhar, poderíamos dizer que o governo Lula criou um ambiente de negócios particularmente favorável ao desenvolvimento do mercado finan-

1. Ainda que seus críticos assinalem o papel benfazejo da conjuntura econômica mundial favorável ao Brasil. ceiro ${ }^{1}$. Mas mesmo assim as eleiçôes de 2006 mostraram que a desconfiança dos "mercados" diante do caráter inerentemente outsider de Lula e de seu grupo não parece ter se desvanecido por completo (cf. Rosa, 2006, 17 ago.; Bergamo, 2006, 22 ago.). Logo, se o setor da sociedade tido como mais 
próximo da racionalidade econômica parece relevar seus interesses materiais em prol de algum tipo de consideração de outra natureza, impõe-se uma análise sociológica da peculiaridade de suas características e dinâmicas, as quais, aparentemente, estariam desviando os "mercados" da perseguição de seus interesses econômicos. Seriam esses "mercados" uma outra coisa que não o cenáculo mesmo da racionalidade, entendida como a busca do maior retorno possível dos esforços despendidos, rigorosamente medidos em unidades monetárias? Haveria, portanto, uma outra lógica, ainda mais poderosa do que a lógica econômica, impelindo os agentes a adotarem posturas que não contemplam integralmente seus interesses materiais? Que deus poderoso seria esse, que desafia as nossas crenças mais arraigadas?

Nosso deus "mercado" dá sinais de ser ainda mais caprichoso do que pensávamos. Insinua-se a evidência de que estamos diante de uma lógica sociológica subsumindo a esperada e intuitiva lógica econômica. Gostos, habitus, atrações \& repulsões estéticas, e questões identitárias em geral têm claramente um papel explicativo nessa trama. Mas como a sociologia pode se aproximar empírica e analiticamente dessa entidade misteriosa que é o "mercado"? Aqui, já dizia Marx, "no acceptance, except for business". Trata-se de um espaço social avesso à investigação sociológica, pelo menos assim pensamos. Dado esse aparente constrangimento, o caminho mais simples é aquele da observação de suas características públicas: as formas através das quais ele se apresenta à sociedade.

Internacional e nacionalmente, o mundo das finanças costuma mostrar à sociedade uma face "democrática" e "inclusiva", na qual ele se alinha em torno da ideia de governança corporativa (GC) (cf. Grün, 2003a, 2005; Brender, 2004; Joseph e Ocasio, 2005). Por outro lado, os desenvolvimentos mais expressivos que observamos "no terreno" são a abrangência cada vez maior do uso de "fundos de private equities" (PEs), tanto no espaço quanto na magnitude dos capitais mobilizados e empregados (cf. The Economist, 2007a, 10 fev.; Cançado e Grinbaum, 2007, 15 jan.; Edmonston e Merced, 2007, 15 maio; Boucher, 2007, 17 jun.; The Economist, 2004, 27 nov.). No Brasil, que não deixa de seguir uma tendência internacional, alguns atores do campo, como os dirigentes dos fundos de pensão e os dirigentes da Bovespa, notabilizam-se socialmente por advogar a extensão cada vez maior da governança corporativa, primeiro no tecido econômico e mais recentemente nos âmbitos social e ambiental, através das ideias de responsabilidade social e de sustentabilidade (cf. Grün, 2003a, 2005). Já os atores que têm impulsionado a propagação dos PEs, mormente aqueles "novos" 
2. Ver na Wikipedia: http:/ /en.wikipedia.org/wiki/ Michael_Milken (acesso em 20/06/07). No verbete transparece a guerra de reputaçôes que tem sido travada recentemente na mídia eletrônica. Ver a respeito Sunstein (2007). banqueiros de investimentos com maior ou menor passagem na administração da política econômica federal e internacionalmente conhecidos como os "Chicago Boys", costumam atuar de maneira discreta, pelo menos em relação à opinião pública que se informa através da grande mídia, ou daquela especializada e aberta.

A GC tem sua origem na militância cívica em prol dos direitos dos consumidores, e desenvolve sua retórica a partir de conteúdos típicos da esfera pública, como transparência e respeito às minorias (cf. McAdam et al., 1996; Joseph e Ocasio, 2005; Davis e Thompson, 1994). Assim, não é por acaso que ela oferece bons argumentos para dourar a imagem dos mercados financeiros nas sociedades e, na esfera interna das finanças, acaba sendo apropriada por atores cujos capitais iniciais para a entrada nas elites são oriundos do campo político ou da militância social. Já os PEs são uma criatura interna do espaço financeiro e, mais do que isso, têm a sua origem moderna associada à emissão dos mal-afamados junk-bonds utilizados na década de 1980 para a aquisição de empresas antigas e o seu subsequente "fatiamento", para a venda de seus ativos a preços cujo somatório seria mais elevado do que os valores de mercado das empresas, fazendo desaparecer a empresa, os empregos e o bem-estar das comunidades das quais elas faziam parte. Essa prática foi considerada imoral e fraudulenta e seus patrocinadores, em especial Michael Milken, acabaram sendo presos². Mas, além da má fama social, o esquema "original" dos FPEs também é associado a lucros muito acima da média daqueles proporcionados por outras alternativas existentes nos mercados na mesma época. Dessa forma, ele se mantém no leque de alternativas razoáveis de investimento, o que pode ser explicado pela teoria moderna da construção de portfólios de investimentos, nos quais convivem alternativas mais seguras e menos lucrativas com outras mais lucrativas e portanto mais arriscadas (cf. Warner, 2007, 5 jul.; Poston, 2006, 9 jan.; Williams e Froud, 2007).

\section{A sociologia de um espaço hostil}

Nesse espaço social que denominamos de "mercados", o senso comum coloca diversas armadilhas específicas para o percurso analítico. Uma questão interessante, e que concorre para sustentar a ideia da existência de um modo de dominação financeiro, é a capacidade demonstrada pelos instrumentos financeiros contemporâneos de apagar o traço das condiçóes sociais de sua existência e desenvolvimento. Eles se naturalizam rapidamente 
e tudo se passa como se sempre representassem um estágio mais elevado da racionalidade econômica e que a sua não existência eterna fosse apenas um acaso já reparado pela ação "natural" do mercado. Trata-se assim de uma institucionalização das relações de força simbólicas, que são enxergadas como parte da natureza e por isso inquestionáveis (cf. Douglas, 1986).

A institucionalização tem como corolário a ideia da irrelevância de uma possível pesquisa empírica sobre a lógica social à qual os atores do mercado estão submetidos. Além disso, é voz corrente que os mercados financeiros seguem uma dinâmica ditada pela "globalização". Por isso, pouca atenção se dá aos seus agentes nacionais, cujas pautas parecem não ter nenhuma independência diante dos constrangimentos internacionais. Entretanto, o olhar analítico mais circunstanciado sobre os mercados financeiros nacionais verificaria que o seu real funcionamento dificilmente seria compreendido se não mirássemos os diversos tipos de intermediários nacionais e regionais que contextualizam as transformações nas línguas e culturas locais. Para além disso, cada vez mais as variaçôes nacionais e específicas de cada subsetor das finanças se mostram relevantes para a explicação das peculiaridades nacionais e setoriais (cf. Godechot, 2001; Beunza e Stark, 2004; MacKenzie, 2006; Folkman et al., 2006). É assim que vemos nossos dirigentes de fundo de pensão (FPs) importarem as tendências internacionais de seu segmento, como o sistema de contribuição definida e a própria ênfase na "boa" governança corporativa. E, do seu lado, Daniel Dantas (DD), o exemplo mais conhecido da nova safra de banqueiros e seus pares, traz para o Brasil as novas ferramentas da financeirização mais aguda, em especial o uso intensivo de "fundos de private equities" (FPEs) e outros mecanismos de concentração de recursos e de pulverização de riscos para o capital. Ao realizar essa tarefa, cada um dos grupos deixa a sua marca, selecionando e dando sentido nacional para as novidades. Mas também é obrigado a levar em conta os constrangimentos produzidos pela presença dos outros no espaço. E, esquematicamente, ao assinalarmos os dois extremos do nosso tabuleiro, poderemos organizar e dar sentido ao material empírico.

Sugiro então que há uma oposição "governança corporativa x private equity", e que ela é um bom caminho para encontrarmos e trabalharmos a tensão essencial que dinamiza o espaço estudado. De início, deve ser considerado que ela não seria diretamente reconhecida pelos participantes do "mercado" e de fato só faz sentido se nos ativermos à esfera simbólica da legitimação da ordem financeira e de seus artefatos ou aos extremos de cada polo. Afinal, no entendimento que prevalece no "mercado" em maio de 2007, "boa 
governança corporativa" é um atributo desejado para qualquer empreendimento, seja ele aberto ao público, como as empresas das quais se compra ações, seja privado, como a compra de participação em negócios pela emissão e compra de private equities. Mas, seguindo a inspiração da filosofia de Nelson Goodman (cf. Goodman, 1988; McCormick, 1996), estamos diante de uma questão de ênfase. Os mesmos elementos podem estar presentes em diversas construçôes simbólicas, mas a ênfase com que cada um deles é aludido faz distinguir um edifício cultural do outro, dando consistência lógica e sociológica à oposição (cf. Bourdieu, 1997). É assim que, tanto na análise sociológica, quanto na esfera simbólica, a oposição GC x PE faz sentido, pois aqueles que gastam seu tempo, energia e dinheiro defendendo cada uma das "ferramentas" são indivíduos e grupos cujos comportamentos públicos permitem-nos situá-los nos extremos opostos do mercado financeiro e também sustentando propostas políticas e sociais distintas para o país.

A situação que observamos em maio de 2007 representa uma evolução do contencioso e das interaçóes sociais no nosso espaço empírico. Acompanhar a evolução e historiar as mudanças de atitude e de sentido é um recurso analítico precioso, pois faz transparecer o jogo social que dá vida ao campo financeiro e mesmo ao campo do poder. Num primeiro momento, os maiores defensores públicos da governança corporativa são os gestores de fundos de pensão, enquanto o PE límpido, destituído dos atributos considerados como característicos da boa governança corporativa, é propagandeado somente por financistas notórios pela cupidez, como Daniel Dantas. Para o primeiro grupo, é a GC que deflagraria no Brasil a dinâmica econômica capaz de nos levar ao "Primeiro Mundo". Já para o segundo, o PE é o principal instrumento para a construção de empreendimentos capazes de revolucionar o capitalismo brasileiro e torná-lo mais próximo do sonhado modelo norte-americano, tido como exemplo de dinâmica econômica e social virtuosa.

À primeira vista, e graças à opacidade que o mundo financeiro consegue produzir ante o resto da sociedade, as diferenças entre os atores, e as estratégias e instrumentos para efetivá-las, parecem cosméticas e fornecem argumentos para a crítica generalizada das atividades financeiras ${ }^{3}$. Mas para ava-

3. Ver, por exemplo, as intervençôes da então senadora Heloísa Helena (PSOL-AL) na inquirição de Daniel Dantas durante a CPI dos Correios, Senado (2005). liar a sua relevância empírica, basta observarmos a enorme disputa pelo controle das empresas de telecomunicações privatizadas, deflagrada no primeiro governo Lula, com as acusaçóes mútuas entre os dirigentes dos FPs e $\mathrm{DD}$, bem como os episódios corolários de acusação de espionagem e tráfico de influência (cf. Michael, 04/08/2004; Duailibi, 2001, 26 abr.). Verifica- 
mos assim que estamos diante de um enorme contencioso. Para os dirigentes dos FPs, DD é a personificação do novo capitalismo selvagem de base financeira que eles têm por missão controlar e debelar ${ }^{4}$. Para DD e os seus, os dirigentes dos fundos de pensão nada mais são do que a nova faceta do famigerado corporativismo brasileiro, contra o qual qualquer golpe é válido, porque eles personificariam o atraso econômico e social do país. E, para completar o esboço, os dois grupos se hostilizam pública e crescentemente pelo menos desde o advento das privatizaçôes de empresas públicas ocorrido no governo de FHC. Poderíamos mesmo dizer que essa disputa está na raiz dos escândalos que sacudiram o primeiro governo Lula (cf. Grün, 2008a). É claro que a disputa pode ser considerada uma guerra restrita aos objetivos declarados dos contendores. Mas a hipótese que creio poder sustentar é mais ampla: estaríamos diante de uma manifestação da disputa básica em torno da configuração que o capitalismo brasileiro deve adotar no presente e nos próximos períodos. Nele, o campo financeiro, no sentido que a sociologia de Bourdieu dá a essa noção, adquiriu centralidade e sua dinâmica interna é decisiva para a conformação dos demais setores da economia. Os outros setores da economia veem cada vez mais restrições à sua autonomia e capacidade de engendrar políticas específicas. Consequentemente, só lhes resta se aliar direta ou indiretamente com um dos adversários dessa contenda na qual o espaço financeiro é o principal objeto e campo da disputa 5 .

As tensões internas do campo financeiro do Brasil, menos evidentes em momentos anteriores, ganharam muita relevância nos governos Lula, na medida em que os dirigentes de fundos de pensão conquistaram espaços políticos e econômicos sem precedentes. A análise de diversas situações nacionais mostra que esses agentes são, normalmente, subordinados e dominados nos espaços financeiros nacionais e, mais ainda, no campo internacional (cf. Montagne, 2006). Não seria demasiado conjecturar que a primeira forma que as private equities tomaram no Brasil do primeiro governo $\mathrm{FHC}$, totalmente restritivas quanto à capacidade de alguns dos seus adquirentes interferirem na administração dos negócios adquiridos ou associados aos fundos, tenha sido desenhada especialmente para conter qualquer veleidade executiva dos fundos de pensão nas empresas recém-privatizadas (cf. Santos, 2007, 18 jun.).

Já no eixo das comparaçôes internacionais, vale mostrar a fragilidade da posição dos fundos de pensão em ambientes capitalistas menos propensos a legitimar essas construções. Recentemente, o Calpers, considerado o maior fundo de pensão do mundo e principal referência da atuação desse tipo de

4. E nesse nosso maio de 2007, quando o segundo mandato de Lula parecia ter "aparado as arestas" dos diferendos, eis que a nomeação de Roberto Mangabeira Unger, indicado e já anunciado para uma secretaria do governo federal, é posta em risco por causa de sua ligação com DD. Ver Camarotti e Gois (2007, 2 jun.) e Alencar (2007, 31 maio).

5. Nesse sentido, o presente texto apresenta uma análise complementar da postulação de que vivemos no Brasil contemporâneo um "modo de dominação financeiro”. Em Grün (2007a), procurei analisar a mesma questão a partir do ângulo cultural, a partir da implantação da GC e das polêmicas sobre o spread bancário. 
6. Em outros governos de corte social-democrata os quadros dirigentes costumam sair $\mathrm{da}$ "ala esquerda das elites tradicionais", como é o caso proverbial francês, no qual se alternam diferentes grupos de egressos da École Nationale d'Administration - ENA. No Reino Unido, a situação é ainda mais adversa aos sindicatos, uma vez que o grupo de Tony Blair fundou o seu "neotrabalhismo" na negação da preponderância tradicional das trade unions no Labour Party. Nesses casos, a ligação das equipes dirigentes na política nacional com os sindicatos e os fundos de pensão que eles patrocinam ou disputam é assim bem menos próxima do que aquela que se vê nos governos Lula. Sobra a curiosa vizinhança da situação brasileira com aquela que observamos nos países escandinavos, em especial a Suécia e a Noruega. Como todos os outros condicionantes nos separam dessas últimas experiências, é razoável afirmar a singularidade da situação brasileira. construção social, passou por um período de militância em prol de causas legitimadas no espaço social, mas não no financeiro (cf. Walsh, 2002, 13 out.). Nesse contexto Arnold Schwarzenegger, o governador da Califórnia, e/ou o seu Partido Republicano teriam aproveitado para interferir na sua administração, destituindo o seu presidente, sem que se levantassem grandes protestos (cf. Walsh, 2004, 2 dez.; Leser, 2004, 3 dez.; Walsh, 2002, 13 out.). Além disso, a própria história dos fundos de pensão brasileiros no período de FHC também mostrou a sua fragilidade, quando, entre outros constrangimentos, se tornou público que seus dirigentes foram forçados a aceitar contratos leoninos na formação dos grupos que iriam disputar a compra das estatais a serem privatizadas, referidas acima (cf. Duailibi, 2001, 26 abr.; Grün, 2003b). E mesmo em tempos de governo Lula, a boa estrela dos fundos de pensão não brilha sempre, como mostrou o episódio da nomeação de Roberto Mangabeira Unger para a secretaria de ações de longo prazo, que é rapidamente registrado pelos players do mercado financeiro como um sinal de fraqueza do grupo a ser eventualmente explorado nas futuras disputas (cf. Romero, 2007, 11 jun.).

No caso brasileiro, uma vez postos na situação "anômala" de dirigentes e responsáveis por parte da condução da economia e do mercado financeiro, os dirigentes dos fundos de pensão e os demais petistas e sindicalistas próximos aos "mercados" terão essa oportunidade, bastante singular em termos internacionais, de revelar e desenvolver o seu projeto econômico e social' ${ }^{6}$. E eis que, ainda numa primeira mirada, eles acabaram gerando uma dinâmica de expansão dos serviços financeiros formais para os estratos menos privilegiados da população. Tivemos assim, entre outras iniciativas ou ênfases, a explosão do crédito subsidiado, a tentativa de "bancarização" universal através do Banco Postal e a extensão das iniciativas de crédito solidário e cooperativo (cf. Cypriano, 2005, 2 abr.; Carvalho, 2007, 8 jun.; Vieira, 2007, 16 maio; Ribeiro, 2006, 23 maio; Thomé, 2007, 29 maio). Já essa primeira onda mostra que a tensão simbólica que assinalamos adquire uma importância inédita na configuração brasileira. Em primeiro lugar, porque ela parece ser uma das principais fontes de dinamização dos mercados financeiros; e, em segundo lugar, porque pode ser responsável por alterações significativas nas esferas econômica e social do país como um todo. Paradoxalmente, poderíamos então adiantar que essa "financeirização de esquerda” do governo petista e de seus sustentáculos sindicais é um componente importante que concorre para a autonomização do campo financeiro brasileiro e para a subordinação dos outros espaços aos seus ditames. 
No espaço das ações de legitimação, podemos discernir um padrão no qual o primeiro grupo participa de um longo entrelaçamento cruzado, juntamente com os estabelecimentos já tradicionais, como grandes bancos comerciais e empresas de seguros que cultivam a responsabilidade social e a sustentabilidade (cf. Grün, 2005). Essas ações marcam uma tentativa robusta de legitimar a esfera das finanças diante da sociedade como um todo e assim, não por acaso, compõem com as moralidades já enraizadas e tendem a manter o campo financeiro mais próximo das outras esferas de sociabilidade. No outro lado do tabuleiro, no qual estão situados nossos novos banqueiros, enxergamos um padrão mais voltado para o público interno, no qual os agentes e empresas se legitimam pela tecnicalidade de suas condutas e, quando conseguimos verificar alguma ação de benemerência aparentemente análoga às da responsabilidade social do outro grupo, verificamos que elas têm um sentido completamente diverso, e mesmo oposto (cf. Grün, 2008a). É assim que, através do seu depoimento na CPI dos Correios, observamos que DD patrocina um projeto de intervenção na educação básica no qual preconiza o uso de incentivos à produtividade do mesmo gênero que se praticam no mercado financeiro (cf. Senado, 2005, 21 set.). Esse lado do tabuleiro parece assim pressionar o campo no sentido inverso, da sua maior autonomia e da consequente subordinação direta dos outros espaços e interesses à lógica interna das finanças, seus habitus e critérios de excelência e de extração de produtividade. E ainda que tal gênero de atuação pareça problemático quando visto de fora do espaço financeiro, é sempre bom lembrar que ele se legitima internamente e, mais importante, fornece modelos de atuação para os recém-entrados no campo, além de constituirse em uma espécie de laboratório a céu aberto para testar as novidades do métier e da ideologia que o acompanha. Poderíamos mesmo dizer que a análise das açōes engendradas desse lado do espectro financeiro poderia generalizar a ideia, contida em Zelizer (1979), sobre a progressiva "moralização" de práticas precificadoras, que acabam produzindo novos mercados para produtos financeiros, dos quais o seguro de vida analisado pela autora seria então apenas um exemplo de uma tendência contínua e secular.

\section{O internacional e o nacional}

Os FPs brasileiros inspiram-se e invocam diversas experiências internacionais. Quando diante dos mercados financeiros e tematizando a GC, sua principal referência é o Calpers (California Public Employees Retirement 
7. E também à audiência televisiva e radiofônica, excitadas pelo escândalo daquele momento, em especial os partidários do governo Lula, que naquele momento enxergavam em Dantas o inimigo principal que teria deflagrado os escândalos para vingar-se da pressão que estaria sofrendo dos fundos de pensão na disputa pelo controle de empresas recémprivatizadas no setor de telecomunicações (cf. Grün, 2008a).
System) norte-americano (cf. Vieira, 2004, 9 jul.; Walsh, 2002, 13 out.). Esse maior fundo de pensão do mundo guarda características que o aproximam da experiência brasileira; a primeira delas, o fato de representar trabalhadores do setor público da economia (no caso, os funcionários do estado da Califórnia). Entretanto, no espaço sindical, a referência mais presente é a europeia, em especial a francesa da CFDT, que preconiza um sistema de épargne salariale que se apresenta como uma alternativa coletivista e socialmente mais defensável do que os sistemas norte-americanos (cf. Jardim, 2007). A ideia mesma de permitir e incentivar a formação e o crescimento de fundos de pensão não é integralmente aceita na Europa sindical, pois ela evoca o neoliberalismo, o primado do indivíduo sobre o coletivo, por serem eles problemáticos para a manutenção da coesão social e intergeracional, além de terem a sua efetividade econômica questionada (cf. Nikonoff, 1999; Lordon, 2000). É assim que se faz uma apresentação dessas instituições na qual o caráter individualista e o sistema de capitalização são consideravelmente eufemizados (cf. Jardim, 2007). Os fundos de pensão brasileiros, em especial aqueles que congregam cotistas oriundos das empresas estatais, irão seguir essa orientação ideológica quando seus dirigentes circulam no espaço sindical. Mas quando mostram a face diante do mercado financeiro, o exemplo norte-americano é que é evocado. No primeiro subespaço, a principal questão levantada é a da solidariedade entre trabalhadores e aposentados, enquanto no segundo a questão da GC, como "ferramenta” econômica, ganha o máximo relevo.

Por sua vez, nas raras aparições públicas de DD, a figura mais emblemática do novo mundo financeiro, ele se justifica para a sociedade invocando o seu papel na importação dos PEs no Brasil. O exemplo mais marcante foi durante a sua inquirição na CPI dos Correios, na qual ele declarou aos presentes $^{7}$ que seu principal feito como financista foi ter convencido o então presidente Cardoso a preparar uma legislação nacional para tornar mais fácil o uso de PEs na construção dos grupos de parceiros que iriam participar nos leilóes do processo de privatização das empresas estatais durante o primeiro termo daquela presidência (cf. Senado, 2005, 21 set.). No episódio, o nosso protagonista discorre sobre as potencialidades do novo instrumento financeiro e também não deixa de registrar o papel que atribui aos PEs no sentido de dinamizar a economia e a inovação tecnológica.

Nosso "tycoon" não fala sozinho. Recentemente, os PEs foram apontados como a grande novidade do capitalismo do século XXI, principalmente pela sua capacidade de concentrar rapidamente grandes quantidades de re- 
cursos em empreendimentos considerados promissores, evitando os atrasos e as inércias imputados aos fundos de investimentos tradicionais, que precisam justificar detalhadamente suas aplicaçōes para seus aplicadores (cf. The Economist, 2004, 27 nov.). Num primeiro momento, essa rapidez é justificada pela necessidade de aproveitar oportunidades que poderiam "escapar", em especial nas aplicaçóes nas start-ups da alta tecnologia. Rapidamente, a mesma justificativa é empregada para evitar embaraços em aplicações de outras naturezas. A crítica dirige-se em especial às questôes associadas com a governança corporativa. E, previsivelmente, a novidade começa a receber fortes críticas pelo seu caráter pouco transparente e pela cupidez dos seus operadores, que se apropriariam de imensas comissões e rendimentos associados sem se comprometerem proporcionalmente com os riscos do negócio e/ou mascarando os riscos vis-à-vis os aplicadores, em especial os fundos de pensão (cf. The Economist, 2007a, 10 fev.; Lambe, 2007; Stelzer, 2007; Williams e Froud, 2007). E mesmo os principais operadores internacionais dos PEs registram as críticas e começam a ter de lidar com elas, lançando uma ofensiva de relações públicas no intuito de melhorar a imagem social de seu ofício (cf. Smith, 2007, 26 jan.; Lerner, 2007).

E nosso DD, da mesma forma que seus êmulos internacionais, responde às críticas sobre a sua administração das empresas de telecomunicações que dirigia assinalando que, se levasse em conta as vontades e as hesitações dos fundos de pensão que se tornaram seus parceiros compulsoriamente, os resultados econômicos de sua gestão não seriam satisfatórios (cf. Senado, 2005, 21 set.). Mas para precisar a cartografia do espaço social que estudamos, é interessante confrontar a postura de DD com a de Fraga e outros players. Enquanto o primeiro enfatiza a necessidade de liberdade do gestor, que lhe confere agilidade, mas traz como consequência a pouca accountability de seus passos, Fraga assinala a necessidade da "boa governança corporativa" para os empreendimentos de PE em que participa (cf. Ribeiro, 2007, 9 maio). Essa diferença de opinião revela tensões importantes no polo "inovador" das finanças e faz sentido quando examinamos as posturas públicas anteriores dos dois atores: enquanto o primeiro aparece para o público como uma espécie de enfant térrible das finanças, que leva ao extremo a lógica interna das ponderações financeiras e nada concede aos seus oponentes e críticos, o segundo dá seguidas mostras de sua ponderação e devoção a causas mais amplas. E enquanto Dantas constrói uma imagem social próxima à do "plutocrata" da primeira metade do século XX, Fraga aparece para a sociedade, e mesmo para os integrantes mais jovens do mercado, como 
um paradigma da boa conduta do agente financeiro (cf. Dávila, 2004, 18 jan.; Grün, 2007b).

Os fundos de pensão, a private equity e a convergência dos atores

Quando os fundos de private equity começam a ganhar visibilidade na cena econômica brasileira, notamos uma forte relutância no seu uso pelos fundos de pensão, que alegavam pouca liquidez, falta de transparência e risco desse tipo de investimento. Mas eles também indicavam as modificações que tornariam aquele tipo de investimento atraente e que pudesse ser adotado pelos FPs (cf. Fortunato, 2003, 8 ago.; Diniz, 2003). Posteriormente, as apreciações se nuançaram, mostrando uma aceitação crescente do novo instrumento, que também vai mudando as suas características. Primeiro, uma reapreciação do instrumento pelo Calpers (cf. Anson, 2004). Em seguida, a "tropicalização" da nova avaliação no Brasil (cf. Gazeta Mercantil, 2004, 5 maio; Carnier, 2005). E finalmente observamos o "sinal verde" da Abrapp - Associação dos FPs - e a sua adoção entusiástica por alguns membros do setor, mais uma vez em consonância com uma tendência internacional dos FPs (cf. News, 2007, 8 jun.; Santos, 2007, 18 jun.; Martins, 2006, 27 abr.; Gilmore, 2007; Revista Fundo de Pensão, 2007). Temos assim um gradiente de posiçôes que torna o nosso campo financeiro um espaço mais complexo e mais entrelaçado do que ele parece à primeira vista.

A análise dessa trama da adoção dos PEs no Brasil recente também pode facilmente escorregar nos automatismos que regem as apreciações das Ciências Sociais relativamente ao jogo das elites e as formas como elas lidam com as lideranças populares. Numa primeira análise, a progressiva aceitação dos PEs pelos FPs poderia indicar simplesmente a capacidade de cooptação exercida pelos novos financistas sobre os dirigentes dos FPs e os partidários de Lula em geral. Mas esse ponto de vista não enxerga a dimensão legitimatória e mesmo "domesticadora" que os últimos têm exercido no capitalismo brasileiro contemporâneo. Se atentarmos para a cronologia, verificaremos que os PEs que se tornaram atrativos para os FPs não são os mesmos que DD preconizava para "alavancar" o processo de privatização das estatais. Agora, e em grande parte por causa das disputas ao mesmo tempo jurídicas e morais entre DD e os FPs em torno da direção das empresas de telecomunicações, os PEs ganharam um nível de accountability e de GC muito mais amplo do que na década anterior (cf. Santos, 2007, 18 jun.). 
Os sentidos mais gerais para esse sistema de oposiçôes podem ser entendidos através do "mapa cultural" desenvolvido por Heap et al. (1992) e Douglas (1996), e na distinção proposta por Hirsch et al. (1990) sobre a diferença entre os sistemas explicativos "limpos" e dedutivos da teoria econômica dominante e os "sujos" e indutivos que são próprios da sociologia. Essa verificação diz que estamos diante de uma variante nacional da dinâmica simbólica típica do capitalismo tardio. De um lado, os advogados dos PEs apresentam-se com uma argumentação elegante, limpa e de bom senso transparente e linear. De outro, os dirigentes dos FPs e seus companheiros de rota apresentam ao debate público uma argumentação menos direta, com vários "no entanto", o chamado "modelo sujo" de Hirsch et al. (1990).

No cerne de cada uma das lógicas, escutamos a pura retórica do mercado do lado dos PEs e um padrão mais matizado para os seus contendores, no qual aparecem as obrigações de reciprocidade advindas de uma visão hierárquica da sociedade. Na primeira, o mundo das finanças mostra um poder de sedução pela lógica da argumentação, que tem prevalecido depois que a Guerra Fria foi vencida pelo Ocidente capitalista. O esconjuro do fantasma do comunismo parece ter libertado o Prometeu dos mercados. Livre do medo do assalto à propriedade privada e aos fundamentos do capitalismo em geral, o mundo financeiro internacional fez desenrolar integralmente o seu pergaminho de prescrições fundamentalistas, no qual maior liberdade econômica e aprendizado por tentativas e erros sempre é uma solução melhor para os problemas sociais e individuais do que qualquer tipo de ajuda direta aos necessitados.

Nesse tempo, a solução para qualquer problema gerado pelo capitalismo é sempre "mais mercado". Os problemas econômicos e sociais são sempre o resultado de uma má alocação dos recursos da sociedade (cf. Douglas e Ney, 1998). Esse mau resultado ocorre por causa de algum impedimento da ação equilibrante das leis de oferta e procura, causado justamente pela decisão fraca e errada de ajudar os perdedores sociais, em vez de aumentar a sua resiliência. Como nos acostumamos, a partir do samba de Paulo Vanzolini, que ressoa uma versão popular da argumentação neoclássica: "um homem de moral não fica no chão, nem quer que mulher venha lhe dar a mão, reconhece a queda e não desanima... levanta, sacode a poeira e dá a volta por cima" ${ }^{8}$. Dessa maneira, por exemplo, não temos um verdadeiro problema de desemprego no país, mas uma simples falta de vontade da sociedade em
8. Versos da música "Volta por cima”, de 1963. 
* A data entre colchetes refere-se à edição original da obra. Ela é indicada na primeira vez que a obra é citada. Nas demais, indica-se somente a edição utilizada pelo autor (N.E.). desimpedir que a oferta e a procura dessa mercadoria se ajustem mutuamente. E a expressão dessa má vontade é a não revogação das leis trabalhistas, que impedem o livre movimento dos preços da mão de obra e dos indivíduos/mercadorias pelo conjunto da economia. Poderíamos dizer que essa sempre foi a opinião dos economistas neoclássicos. Entretanto, o decisivo no conflito cultural não é a arqueologia dos pontos de vista, mas a capacidade de sustentar publicamente essa posição que para muitos parece inescrupulosamente antissocial, sem que ela seja considerada indizível. Dificilmente isso aconteceria enquanto o fantasma do comunismo ainda assombrasse o Ocidente. Depois que ele se desvaneceu, a advocacia do "livre comércio da mercadoria força de trabalho" se tornou corriqueira, no sentido de não mais provocar indignação social. Parece assim evidente que estamos diante de um novo tipo de darwinismo social, tornado robusto pela opacidade.

De seu lado, os nossos "domadores do capital financeiro" podem ser inscritos numa linhagem de pensamento e ação cujas manifestações mais recentes foram a tentativa de frear a inflação através de acordos explícitos sobre os conflitos distributivos que estariam na raiz do fenômeno (cf. Singer, 1988a); e as câmaras setoriais e regionais, que propunham regular as relaçôes entre as partes econômicas e sociais e os diversos níveis de governo na esfera de cada setor produtivo ou região (cf. Zilbovicius e Arbix, 1997). Notemos que estamos diante de uma evolução nuançada na qual, se parece haver uma ruptura quando os atores deixam de privilegiar a esfera da produção para adentrar no espaço das finanças, por outro lado seu posicionamento no mundo das finanças é tributário e análogo ao da situação anterior. De "concertantes" do capital industrial que enfatizavam as ligaçóes entre a esfera econômica e a social, eles se transformam em domadores das tendências mais agressivas e (re)ordenadores das funçôes tradicionais do capital financeiro. Em ambos os casos, como que ecoando a digressão de Polanyi ([1944]* 2001), eles se colocam como portadores de uma lógica social necessária para resguardar a humanidade das derivações perversas das atividades econômicas e financeiras. E, se consideramos a dimensão legitimatória de suas ações, no sentido de expandir pela sociedade o alcance das facilidades da formalização financeira e assim incluir vastas camadas da população entre os interessados diretos na vitalidade do sistema financeiro, concluiremos que os FPs são um agrupamento fundamental para a manutenção do status quo econômico que emerge da paradoxal situação política engendrada pelos governos Lula. Mas, proverbialmente, eles são vistos por seus adversários financistas como os principais representantes do atraso eco- 
nômico, porque estariam tentando limitar a livre expressão das forças e da lógica dos mercados. Nesse sentido, uma acusação frequente é aquela que imputa ao governo Lula a intenção ou a simples consequência de implantar no Brasil uma "República sindical”, que seria implicitamente ilegítima diante dos outros possíveis clusters de recrutamento de pessoal político e gerencial (cf. Scholz e Arruda, 2006, 21 set.; Folha de S. Paulo, 2006a, 21 set.; Michael, 2003, 29 set.). Além disso, também se depreende da mídia que as maneiras plebeias de Lula e de parte de seu grupo, a pauta de extensão da financeirização e principalmente as tentativas de manter ligações e alguma composição de interesses com os setores não financeiros da economia, que acabam diminuindo a autonomia da esfera financeira, são taxadas de corporativistas e não parecem ser do agrado das elites (cf. Rosa, 2006, 17 ago.; Bergamo, 2006, 22 ago.).

A tensão simbólica que aparece na sociedade brasileira pode ser considerada a versão nacional de uma tendência mais ampla do capitalismo "financeirizado". Como o oportunismo e as condutas arriscadas em geral são comportamentos inerentes ao sistema e normalmente considerados corajosos e inovadores, a sua regulação acaba se fazendo a partir de espasmos periódicos, em geral em momentos imediatamente posteriores a alguma crise. Aí, a introdução de alguma mudança de cálculo de risco, novo tipo de papel ou esquema de financiamento deixa de ser considerada uma "inovação" e seus proponentes, primeiramente incensados como empreendedores e visionários, passam a ser execrados, e suas ações são então consideradas "simples aventuras" ou "escroquerias" (cf. Galbraith, 1993; Abolafia, 1996; De Blic e Limeux, 2000, 2005; Coffee, 2002; Blair, 2003).

Um exemplo contemporâneo da tendência são os grandes escândalos empresariais norte-americanos do início da década (Enron, Xerox, Worldcomm), que obrigaram a uma nova rodada de regulamentação mais estrita do mercado de capitais daquele país, gerando a lei Sarbanes-Oxley (Sox). Antes da derrocada, a Enron era vista como um paradigma internacional de empresa moderna, um modelo de gestão "de pessoas" e de recursos a ser imitado por todas as organizaçōes, não só as do setor elétrico. Depois da publicidade negativa que enfatizou os malfeitos daquela empresa, o exemplo deixa subitamente de ser evocado, sem qualquer tipo de crítica ao seu uso anterior. E, uma vez tendo os escândalos perdido a sua eficácia simbólica reguladora, eis que nosso Prometeu procura se desvencilhar das amarras recém-introduzidas. É assim que diversos atores do mercado financeiro reclamam dos excessos regulatórios da Sox e alegam que isso prejudica o 
mercado norte-americano, pois afugenta as companhias daquele local, em benefício da praça de Londres (cf. Labaton, 2002, 19 out.). Além disso, os presidentes e altos executivos de grandes empresas de capital aberto, que têm sido muito atacados por causa de suas remunerações consideradas excessivas e sem relação com o desempenho das ações das empresas, encontram pagamentos mais substanciais nas empresas de capital fechado controladas pelos PEs (cf. Sorkin, 2007, 8 jan.). E então começa o previsível ataque aos "legisladores e burocratas irresponsáveis". Eles estariam prejudicando o dinâmico mercado de capitais norte-americano, que atrai investidores de todo o mundo, deixando assim escapar para a City londrina o trunfo que, desde os bons tempos econômicos dos anos da presidência de Bill Clinton, tem sido considerado a principal fonte de prosperidade daquela economia (cf. Conway, 2007, 5 jun.; The Economist, 1994).

Em suma, as soluções preconizadas para dar conta da instabilidade estrutural da economia financeirizada são medidas de regulamentação que tolhem a anterior liberdade de movimentos do capital. Se podemos inferir que elas conferem maior estabilidade ao sistema no longo prazo, isso não anula o fato de que os operadores dos mercados sintam o golpe contra o business as usual, principalmente porque novos ambientes costumam elevar novos indivíduos e grupos e eclipsar antigos. Vai daí que encontramos novas formas de expressão do paradoxo apontado pelos marxistas sobre a diferença entre os interesses da classe capitalista e dos capitalistas individuais. $\mathrm{E}$ também uma boa explicação para o "estranhamento" entre Lula e os portavozes reconhecidos das elites econômicas.

\section{0 campo financeiro}

Tanto a análise da cena nacional quanto a da internacional sugerem a pertinência de estabelecermos uma categorização dos atores e do espaço baseada na noção de campo (cf. Bourdieu, 2000). Querendo ou não, detestando-se e invejando-se mutuamente, os atores e os grupos inseridos no espaço financeiro acabam engendrando um entrelaçamento que, visto diretamente, parece um simples processo de competição. Mas quando observamos a cena em detalhe, encontramos uma cooperação objetiva, a ponto de podermos dizer que nossos diversos players vivem num estado de equilíbrio dinâmico. Como em outras cartografias sociológicas de espaços econômicos, temos um setor estabelecido, formado principalmente pelos grandes bancos comerciais, mais interessados na estabilidade das posiçôes relativas 
do que na mudança da configuração (cf. Fligstein, 1990). Ao seu lado temos um grupo de "vanguarda", formado de novos agentes estabelecidos no ramo há pouco tempo (cf. Thompson, 1997), que se instalam propondo serviços ainda não oferecidos pelos atores tradicionais, e que são, em geral, adaptações para o Brasil de produtos financeiros já existentes nos mercados mais desenvolvidos, em especial o norte-americano e o inglês. Situam-se nessa rubrica os PEs, mas também outros produtos recentes, como os fundos de recebíveis, os fundos de hedge e os imobiliários (cf. Dávila, 2004, 18 jan.). E, no setor mais dominado do espaço, encontramos pequenas empresas de corretores independentes tradicionais e os nossos atores ligados aos fundos de pensão. Os primeiros chegaram ao "fundo do poço" no final do período FHC (cf. Ripardo, 2002b, 20 ago.). Os últimos manejam montantes expressivos de capital, mas, fora da "temporada atípica" dos governos Lula, (ainda) não demonstraram muita capacidade de fazer a sua pauta influir no campo.

$\mathrm{Na}$ calmaria social posterior à queda do comunismo europeu, as "vanguardas financeiras", representando o setor desafiante do campo, detiveram um enorme poder de sedução sobre as demais elites da sociedade capitalista, só impedido em momentos como os dos escândalos financeiros, mas rapidamente recuperado. Poderíamos então levantar duas questôes, em diferentes níveis de generalidade. A primeira diz respeito ao canto de sereia que as finanças entoam, que inebria parte das elites tradicionais e também atrai decisivamente setores recém-chegados ao campo do poder, como é o caso dos sindicalistas e políticos brasileiros oriundos dos sindicatos. Vimos que a sociabilidade financeira fornece boas localizações sociais para a construção de teodiceias dos novos entrantes, justificando as suas posiçôes e mesmo conferindo-lhes referências identitárias fundamentais para sua manutenção no espaço recém-conquistado. Mais genericamente, o atual predomínio da razão financeira pode ser associado à solução de diversos problemas, tanto novos quanto tradicionais, que são ou podem ser resolvidos pela expansão e refinamento dos serviços financeiros. No espaço estritamente econômico, vimos que a difusão dos arranjos de PE fornece um novo e atraente quadro de referência que propicia a aplicação de enormes magnitudes de capital que tem sido aplicado no agronegócio no início do século XXI e também em várias reorganizações societárias (cf. Rosa, 2007, 8 fev.; Palhano, 2007, 16 abr.; Valor Econômico, 2007, 25 jan.). Num plano paralelo, eles também fornecem ferramentas econômicas e cognitivas que tornam os patrimônios familiares das elites econômicas mais mensuráveis e 
líquidos, abrindo espaço para reposicionamentos intraclânicos. Essas novidades poderão beneficiar principalmente os membros por tradição "não ativos" das famílias, como as herdeiras e as mulheres em geral. Generalizando, poderíamos dizer que a nossa "precificação" é um corolário recente do ato tradicional de "botar um preço" em propriedades, serviços ou atitudes, que indica a transformação de um objeto ou evento de sagrado em profano. Ao abrir novas maneiras de engendrar essa possibilidade, a financeirização recente constrói um quadro de referências distinto dos anteriores para disputas e negociações não só entre empresas e setores das elites, mas também internamente às famílias dinásticas, criando novas formas de mensuração e repartição de patrimônios. No seio dessas famílias, observa-se assim a possibilidade de novos tratamentos de contenciosos potenciais ou já deflagrados, e de manutenção de concentração de capitais que, em outros tempos, estariam fadados a serem pulverizados por disputas intestinas (cf. Anaya, 2002, 12 dez.; Cavalcanti, 2004, 26 fev.; Valor Econômico, 2001, 31 ago.).

Mas será que a sociedade como um todo aceita o padrão de sociabilidade econômica que as finanças estão tentando lhe impor? Ainda que a atual falta de reação pública visível e mesmo a nossa "financeirização de esquerda" indiquem que sim, o acumulado histórico é mais nuançado. A adoção generalizada dos PEs significa uma intromissão direta da razão financeira na esfera industrial, cuja aceitação está longe de ser bem absorvida. Mesmo nos Estados Unidos, país que os financistas costumam adotar como o bom exemplo para o desenvolvimento de seu ofício, a recente aquisição da empresa automotiva Chrysler por um fundo de private equities foi vista como um evento exótico, a ser observado e eventualmente impugnado. Os PEs são ferramentas legítimas quando se trata de financiar pequenas empresas nascentes de alta tecnologia através do venture capital, mas muito menos quando tentam se imiscuir no cerne da corporated America, em especial no setor automobilístico, com sua mística nacionalista e sindical (cf. Edmonston e Merced, 2007, 15 maio). E na cauda da crítica ao "atrevimento" dos PEs surgem as inevitáveis tentativas de controle político sobre a atividade e a sua maior taxação, mostrando outra face do controle social da atividade financeira (cf. Sorkin e Merced, 2007, 22 jun.; Sorkin e Anderson, 2007, 23 jun.). Como quer o ditado muitas vezes proferido pelos financistas, " mico que pula muito quer chumbo".

No Brasil, refletindo uma característica norte-americana adquirida no final do século XIX (cf. McGerr, 2005), durante muito tempo os bancos foram impedidos de investir diretamente na esfera industrial, pois sua 
capacidade superior de mobilizar capitais em qualquer ramo tornaria desleal a concorrência contra grupos sem essa propriedade. Essa proibição vigorou até a lei da informática e refletia a sensibilidade de que a sociedade deve se precaver contra os excessos da lógica financeira. Não por acaso, ela reflete também uma necessidade da legitimação da atividade financeira internacional.

Já em $O$ capital, Marx insiste que o capital financeiro no senso estrito (abstraindo aí os bancos como empregadores diretos), por ser remunerado através de punçôes realizadas sobre o lucro do capitalista produtivo, aparece na sociedade não como inimigo dos trabalhadores, mas como inimigo do capital industrial, esse último sim o inimigo dos trabalhadores (1976, vol. 3, cap. 24). Dessa posição, os grandes financistas podem até aparecer como amigos dos trabalhadores, já que são inimigos dos seus inimigos e agora pródigos filantropos (cf. Guilhot, 2006). A crítica recente parece inocentar aqueles que seguem o caminho de que Soros está sendo o exemplo mais evidente. Mas ela se reacende quando o capital financeiro invade diretamente a área industrial, a do "trabalho de verdade". Um dos sintomas mais fortes dessa sensibilidade aparece quando constatamos que a indústria cultural tem produzido diversos filmes comerciais que têm por tema o exagero da dominação financeira. Como que ecoando a crítica de Proudhon, normalmente, o pecado apontado é que, nesses períodos de fusōes e incorporações de empresas que o mundo econômico vive desde a década de 1980, os financistas e os apetites gerados no seu ofício invadem áreas da sociabilidade que deveriam ser sagradas, em especial o mundo da indústria e do trabalho (cf. Grün, 1994). Exemplos romanceados dessa conspurcação foram os filmes Com o dinheiro dos outros (1991), de Norman Jewison, e Selvagens em Wall Street (1993), de Glenn Jordan, nos Estados Unidos, e De gré ou de force (1998), de Fabrice Cazeneuve, na França.

Uma hipótese interessante, reforçada pelo desfecho da eleição presidencial de 2006, é que o processo de privatização das indústrias estatais brasileiras, ocorrido fundamentalmente na década de 1990, tenha despertado, ou feito aflorar, esse gênero de sensibilidade. Numa primeira visão, integralmente tributária da doxa econômica, ela seria apenas a reação à forte tendência de aumento das tarifas dos serviços públicos que ficou associada à reorganização societária das privatizações. Evidentemente, no espírito da doxa, os argumentos contra a privatização e seus operadores são respondidos pelo aumento da oferta de serviços de telefonia, que por sua vez são creditados à maior agilidade das companhias, resultado das reorganizações 
pós-privatização (cf. Anuatti-Neto, 2005). Mas a cena cultural revela um contencioso muito maior, quando a fricção ideológica produz, ou faz ressurgir, personagens exóticos ou aparentemente anacrônicos para a sociedade brasileira do início do século XXI. O surgimento de figuras públicas a partir de um roteiro que normalmente se associa ao dos plutocratas do final do século XIX e primeira metade do XX indica esse gênero de malaise social. Dos possíveis candidatos brasileiros à duvidosa posição de plutocrata, DD e Steinbruch seriam então os mais indicados para ganhar a dianteira no processo. Como Steinbruch voltou-se para a produção de aço, abandonando os setores prestadores de serviços públicos, diminuiu sua exposição na mídia. Sobra assim DD, que incorpora o halo da reação à privatização e das mudanças subsequentes nos preços, e também o da alteração dos tipos de serviços que as empresas prestam (cf. Grün, 2007a).

A agenda econômica e política suscitada pelas eleições presidenciais de 2006 acabou assim gerando um amplo e interessante mirante panorâmico para observarmos a base cultural que subsume a atividade econômica na sociedade brasileira atual. Uma vez que a argumentação que absolutiza a razão financeira impacta fortemente as elites, supunha-se que ela teria a mesma repercussão na população em geral, ou pelo menos que a sensibilidade das elites acabasse prevalecendo sobre as percepções populares originais. Tanto é assim que a repercussão do "golpe" desferido por Alckmim em Lula no debate televisivo de 7-8 de outubro de 2006, insistindo na venda do "Aerolula" (cf. O Globo Online, 2006, 8 out.), que pareceu às elites um quase nocaute, acabou revelando a forte sensibilidade popular antiprivatização. E naquele momento quente em que os "tools-kits" culturais estavam sendo freneticamente revirados para construir argumentos em prol das candidaturas próprias e contra a dos adversários, a argumentação antiprivatização foi rapidamente incorporada à campanha e à retórica de Lula (cf. Rodrigues, 2006, 5 nov.), para surpresa generalizada e mesmo desalento dos "fazedores de opinião" (cf. Sardenberg, 2006, $1^{\circ}$ nov.; Góis, 2007, 6 jan.; Folha de S. Paulo, 2006b, 19 out.; Lamucci, 2006, 24 out.).

Essa configuração sugere uma divisão interessante, na qual as diversas elites brasileiras crescentemente aceitam e utilizam essa versão contemporânea do commerce doux como mecanismo de resolução de seus diferendos, mas também que esse enquadramento cultural não é integralmente aceito pelos demais setores da sociedade. Mais do que isso, percebendo essa ruptura cultural, os setores recém-chegados, quando colocados na situação limite em que estão por ser expulsos daquele espaço, utilizam o mal-estar 
popular para negociar seus lugares no campo do poder, ainda que não fique claro se eles renegam a doxa elitista ou utilizam o discurso antiprivatização apenas situacionalmente (cf. Rodrigues, 2006, 5 nov.). Sendo ou não uma "traição", essa configuração revela um mecanismo interessante de integração social que age simultaneamente na esfera das elites e na esfera social mais ampla, e que pode ser a matriz para mudanças importantes na sociedade brasileira contemporânea.

Nosso commerce doux redivivo é a sociabilidade engendrada pela lógica da atividade econômica na sua forma mais direta que são as finanças, aplainando progressivamente as arestas entre os diversos setores das elites, que mantêm seus interesses e sensibilidades distintas, mas encontram na linguagem financeira um ponto de convergência mutuamente vantajoso, capaz de valorizar os diversos capitais específicos (cf. Hirschman, 1986; Grün, 2005). Assistimos assim a essa dupla entrada das novas elites oriundas do sindicalismo e dos movimentos sociais e ambientais no campo do poder. Elas adentram aportando uma caução importante na esfera legitimatória, reforçando o predomínio das finanças ao estender essa teia a novos e vastos setores da população. Ao lapidarem diversos instrumentos financeiros e assim permitirem a sua difusão muito mais ampla em benefício próprio e também dos seus concorrentes no espaço econômico, elas estão construindo um nicho para si mesmas no espaço financeiro e no campo do poder.

A "prova do pudim" da nova configuração econômica e social aparecerá num previsível futuro governo federal menos afinado com os políticos oriundos do sindicalismo e dos movimentos sociais e ambientais. Nesse caso, nossos novos atores conseguiriam manter todo ou parte do poder que obtiveram nos últimos anos? Ou seriam tangidos para fora do espaço das elites, o que demonstraria que o seu poder econômico é totalmente dependente do acaso do poder político alcançado nas eleições presidenciais de 2002 e 2006? Afinal, ainda que possamos demonstrar analiticamente a convergência que deveria interessar a todos, os escândalos que balançaram o primeiro governo Lula e ameaçaram a sua reeleição mostram que as diferenças e desconfianças mútuas continuam grandes e mesmo aumentaram conjunturalmente (cf. Rosa, 2006, 17 ago.; Grün, 2008a).

Numa primeira tentativa de síntese analítica, poderíamos dizer que estamos assistindo a um roteiro concreto da forma pela qual se realiza a ação profilática das elites nacionais no sentido de proteger o tecido social da infecção generalizada que seria a utopia do mercado autorregulado se tornando a medida para toda a sociabilidade. Teríamos assim achado a mi- 
cropolítica da versão brasileira contemporânea dessas defesas que o ardil da razão social acaba produzindo, e assim estaríamos coonestando e contextualizando a análise seminal de Polanyi (2001). Mais genericamente, estaríamos também confirmando a intuição de Schumpeter (1991), para quem a esfera das finanças revela a ossatura da sociedade capitalista contemporânea, em especial do seu âmbito político e das disputas entre suas elites. E nada mais razoável do que ter em conta que, numa sociedade tangida pelo modo de dominação financeiro, tal profilaxia só pode ser engendrada a partir desse constrangimento estrutural.

Através da nossa "financeirização de esquerda", o ardil da razão social empurra para o âmbito das finanças e para o campo do poder em geral lideranças de setores da sociedade que em estados anteriores do campo do poder poderiam opor severa resistência aos seus ditames. Essas novas elites freiam e filtram as pressões sociais, em especial aquelas específicas de seus espaços de atuação iniciais, ao mesmo tempo em que escavam seus lugares na nova configuração. Assim fazendo, elas aumentam a estabilidade e a legitimidade do campo financeiro e do campo do poder na sua generalidade. Mas essa recomposição das elites não pode fazer-se sem reação dos antigos ocupantes das posições de intermediários, os quais subitamente perdem parte das suas atribuições e reagem à nova situação. Já acostumados com a sociabilidade das elites, também nada mais previsível do que vê-los deplorarem a "falta de compostura" de seus substitutos. E assim assistimos aos escândalos do primeiro governo Lula, que passam a ser fenômenos sociologicamente previsíveis. Diversos tipos de intermediários políticos e intelectuais já estabelecidos têm a sua função e posição posta em julgamento e os escândalos passam a ser a sua forma de expressão e luta para a conservação da "reserva de mercado". O enjeu não é pequeno, pois se trata do reconhecimento social em diversas dimensões, indo desde a esfera profissional no seu senso estrito até o direito de frequentar as elites exibindo a condição de intérpretes dos anseios e das opinióes do público ou dos deserdados. E então passa sobre os olhos da população brasileira essa guerra de reputações, configurada como uma sucessão de escândalos virulentos, na qual um episódio parece sempre suscitar a sua continuação, trazendo essa impressão de autoflagelação permanente do campo político (cf. Grün, 2007a). É assim que avoco aos escândalos do primeiro período da presidência de Lula o caráter de verificadores da tensão social que perpassa o campo do poder brasileiro nesse processo de inclusão de novos grupos e de seu inevitável questionamento por outros segmentos já estabelecidos. 
Numa esfera mais microssituada, as evidências sobre a importação e posterior difusão dos PEs no tecido econômico brasileiro mostram também a relação complexa que as ferramentas financeiras têm nos contextos sociais que as aprovam, filtram, lapidam e legitimam. De um lado, elas são o objeto da ação de diversos setores da sociedade, os quais, progressivamente, nela vão deixando a sua marca. Mas, por sua vez, também contribuem para rearticular as práticas e, consequentemente, as consciências e habitus. $\mathrm{Na}$ sua versão original, os PEs instituem, na esfera sociocognitiva e social, uma diferenciação aguda entre dinheiro e empresa, e dessa forma também entre a figura do investidor e a do empresário. Ao produzir essa divisão, eles contribuem para reconfigurar uma série de comportamentos sociais, em especial na esfera das elites econômicas. $\mathrm{O}$ retrabalho posterior realizado pelos agentes "sociais" talvez tenha diminuído a oposição cognitiva, mas é matéria empírica a sua apropriação na esfera das famílias dinásticas e outros grupos que podem fazer uso da ideia de PE para tratar seus contenciosos.

Por fim, o caminho traçado pelos PEs mais recentemente guarda analogia com o empreendido pela GC no passado um pouco menos próximo. Esta última "ferramenta" surgiu no Brasil como um produto importado por economistas e advogados recém-chegados de períodos de estudos nos Estados Unidos, que precisavam se estabelecer no espaço nacional e para isso usaram o conhecimento desse instrumento como um fundo de comércio. Posteriormente, no seu processo de difusão e aclimatação, o "fundo de comércio" foi sendo perdido pelos primeiros, mas a sua apropriação por diversos conjuntos de atores produziu o enraizamento da novidade, primeiro no tecido econômico (cf. Grün, 2003a) e depois, pela responsabilidade social e pela sustentabilidade, no espaço social (cf. Grün, 2005). E tanto no primeiro movimento da GC quanto no segundo, a ação dos atores cujos capitais originais são advindos da esfera política e social, ao mesmo tempo se apropriando da novidade e moldando-a ao contexto brasileiro, foi decisiva para a sua difusão.

Concluindo, podemos então afirmar que a "mágica" da introdução dos novos instrumentos financeiros no Brasil é realmente um fenômeno bem mais amplo do que a simples adoção de um nível de racionalidade econômica e financeira mais elevado do que no passado. Antes, ela é o resultado de um complexo processo de interações sociais que altera posições relativas no campo econômico, no campo sindical e também no campo do poder. E ao gerar essas mudanças, produz também novos enquadramentos cognitivos para dar conta dos equilíbrios, e alterá-los, em diversas esferas, como a 
das vidas domésticas de diversos segmentos da população e a da noção mesma do que é a atividade econômica e empresarial. Aqui, as "ferramentas" acabam sendo utilizadas para propósitos que não são coincidentes com aqueles de seus formuladores originais e também produzem resultados inesperados. E uma armadilha analítica comum é a de procurar sistematicamente apenas os resultados que são esperados nos ambientes de origem dos novos instrumentos financeiros, obliterando todo esse rico processo de pesquisa das apropriaçôes diferentes e diferenciais que lhes dão vida nos trópicos.

\section{Referências Bibliográficas}

Abolafia, M. (1996), Making markets: opportunism and restraint on Wall Street. Cambridge, Mass., Harvard University Press.

Alencar, K. (2007), "Lula quer que Mangabeira desista de cargo. Presidente espera que filósofo, que move processo contra Brasil Telecom, recuse convite para secretaria”. Folha de S. Paulo, São Paulo, 31/05.

AnaYa, V. D. M. (2002), "Mudanças no Pão de Açúcar começam em março. Grupo terá dois polos administrativos: um conselho e uma diretoria executiva”. O Estado de S. Paulo, São Paulo, 12/12.

Anson, Mark. (2004), "Trends in private equity". The Journal of Wealth Management, 7 (3): 84-90.

Anuatti-Neto, F. (2005), "Os efeitos da privatização sobre o desempenho econômico e financeiro das empresas privatizadas". Revista Brasileira de Economia, Rio de Janeiro, 59 (2).

BARBIERI, C. (2007), "Estrangeiras lançam papéis na Bovespa. No período de um ano, quatro empresas fazem oferta de BDRs. Até 2008, mais cinco devem chegar ao mercado local. Especialistas acreditam que a Bovespa se tornará o mercado de maior liquidez da América Latina, o que deve atrair mais empresas”. Folha de $S$. Paulo, São Paulo, 04/06.

Bergamo, M. (2006), "Lula afirma a artistas que elite quis fazê-lo 'sangrar". Folha de S. Paulo, São Paulo, 22/08.

BeunZa, Daniel \& STARK, David. (2004), "Tols of the trade: the socio-technology of arbitrage in a Wall Street trading room”. Industrial and Corporate Change, 13 (2): $369-400$.

BlAir, M. M. (2003), "Reforming corporate governance: What history can teach us". Social Science Research Network (disponível em http://papers.ssrn.com/sol3/ papers.cfm?abstract_id=485663\#PaperDownload).

Boucher, E. L. (2007), "La société agressive par actions". Le Monde, 17/06. 
Bourdieu, P. (1997), Méditations pascaliennes. Paris, Seuil. . (2000), Les structures sociales de l'économie. Paris, Seuil.

Brender, A. (2004), La France face aux marchés financiers. Paris, La Découverte.

Camarotti, Gerson \& Gois, Chico de. (2007), “Daniel Dantas elogia Mangabeira; PT tenta impedir nomeação. Assessores dizem que Lula está indeciso em manter indicação. Alencar afirma que não é 'padrinho' do filósofo”. O Globo, 02/06.

CANÇADO, Patrícia \& Grinbaum, Ricardo. (2007), “Investidores financeiros são a nova cara do capitalismo no Brasil: Investidores financeiros são a nova cara do capitalismo no Brasil”. O Estado de S. Paulo, 15/01.

CARnier, T. (2005), "Capital de risco: oportunidade para empreendedores, um mercado crescente para elevar o lucro das carteiras”. Revista da Bovespa, jul.-ago.

Carvalho, M. C. (2007), "BC conta com as cooperativas para estimular a competição". Valor Econômico, 08/06.

Cavalcanti, M. (2004), "A retirada dos Ermírio: Empresa cria uma nova holding para abrigar a família e inicia a era da profissionalização nos negócios". Istoé_Dinheiro, 26/02.

Ciarelli, M. \& Farid, J. (2002), "Açôes migram para os Estados Unidos. Mais da metade dos papéis das principais empresas nacionais é negociada nos EUA". $O$ Estado de S. Paulo, São Paulo, 25/02.

CNI. (2007), "Melhor cenário em 2007 não deve beneficiar toda a indústria". Informe Conjuntural da Confederação Nacional da Indústria, ano 23, n. 1, jan./mar.

Coffee, J. C. (2002), “Understanding Enron: It's about the gatekeepers, stupid”. Columbia Law School, The Center for Law and Economic Studies, Working Paper n. 207.

Conway, E. (2007), "Darling won't clamp down on private equity tax”. The Telegraph, 05/07.

Cypriano, M. A. L. (2005), “'Bancarização': os bancos chegando a toda a população brasileira”. Seminário Comandatuba, Febraban, 02/04.

Damé, L. (2007), "Lula: Bolsa deve agradecer ao governo. Presidente diz que dirigentes tinham medo dele em 2002". O Globo, 18/05.

DÁvila, S. (2004), “República do Leblon cresce e aparece”. Folha de S. Paulo, 18/01.

Davis, Gerald \& Thompson, Tracy. (1994), "A social movement perspective on corporate control". Administrative Science Quarterly, Ithaca, 39: 141.

De Blic, D. \& Limeux, C. (2000), "Le scandale financier du siècle: ça ne vous intéresse pas? Difficiles mobilisations autour du Crédit Lyonnais”. Politix, 13 (52). . (2005), "Le scandale comme épreuve: éléments de sociologie pragmatique". Politix, 18 (31): 9-38.

DiAnNi, Claudia. (2007), "Lula defende nacionalismo e Bovespa. Presidente afirma 
que Bolsa, onde só entrou após 'muita labuta', deve agradecê-lo por ter deixado de ser um 'enfeite'. Folha de S. Paulo, São Paulo, 18/05.

Diniz, D. (2003), "Private equity e venture capital - o que falta para esse mercado decolar?”. Revista Fundos de Pensão, 284, maio.

Douglas, M. (1986), How institutions think. Syracuse, Syracuse University Press. . (1996), Thought Styles: Critical Essays on Good Taste. Londres/California, Thousand Oaks/Sage.

Douglas, M. \& NeY, S. (1998), Missing persons: a critique of the social sciences. Berkeley, University of California Press/Russell Sage Foundation.

DuAiLibI, J. (2001), "Ex-ministro Mendonça de Barros depõe na Justiça e diz que escuta serviu a vencedor no leilão da Telebrás: Mendonça liga ex-diretor do BB a grampo". Folha de S. Paulo, 26/04, A13.

Edmonston, P. \& Merced, Michael J. de la. (2007), "Cerberus goes where no firm has gone before". The New York Times, 15/05.

FLigstein, N. (1990), The transformation of corporate control. Cambridge, Mass., Harvard University Press.

FolHa DE S. PAulo. (2006a), “Aécio diz que Lula teve 'pouco cuidado' na indicação de cargos de confiança”, 21/09.

_. (2006b), "PT impôs agenda a Alckmin, dizem cientistas políticos", 19/10.

FolKman, Peter, Froud, Julie, Johal, Sukhdev \& Williams, Karel. (2006), “Working for themselves?: Capital market intermediaries and present day capitalism”. CRESC, The University of Manchester (disponível no site http://www.cresc.ac.uk/ publications/papers.html), nov.

Fortunato, D. (2003), "Fundos de pensão divergem sobre investimento em 'private equity': Pimentel, presidente da Abrapp, acredita que os ativos de risco não são ideais pela falta de mercado secundário". Valor Econômico, 08/08.

Galbraith, J. K. (1993), A short history of financial euphoria. Nova York, Whittle Books/Viking.

Gazeta Mercantil. (2004), “Private equity terá nova regra no Brasil”, 05/05.

Gilmore, W. (2007), "Private equity: some of the most significant investors in private equity are now pension funds". Global Investor, 202: 48-49.

Godechot, O. (2001), Les traders essai de sociologie des marchés financiers. Paris, La Découverte.

Gois, Chico de, Jungblut, Cristiane \& Damé, Luiza. (2007), “Lula sanciona lei do saneamento e abre caminho para investimentos: ao aprovar o marco regulatório do setor, presidente faz críticas à privatização". O Globo, Rio de Janeiro, $06 / 01$.

Goodman, N. (1988), Ways of worldmaking. Indianapolis, Hackett Pub. Co. 
GRÜN, R. (1994), “O estreitamento das classes médias norte-americanas”. Revista Brasileira de Ciências Sociais, 9: 130-133.

. (2003a), "Atores e ações na construção da governança corporativa brasileira". Revista Brasileira de Ciências Sociais, 18 (52): 121-143.

. (2003b), "Fundos de pensão no Brasil do final do século XX: guerra cultural, modelos de capitalismo e os destinos das classes médias". Mana - Estudos de Antropologia Social, 9 (2): 7-38.

______. (2005). "Convergência das elites e inovações financeiras: a governança corporativa no Brasil”. Revista Brasileira de Ciências Sociais, 20 (58): 67-90.

. (2007a), "Decifra-me ou te devoro: as finanças e a sociedade brasileira". Mana - Estudos de Antropologia Social, v. 13, pp. 381-410.

. (2007b), "Entre a plutocracia e a dominação financeira". Revista Brasileira de Ciências Sociais, 22: 85-107.

. (2008a), "Escândalos, marolas e finanças: para uma sociologia da transformação do ambiente econômico”. Dados - Revista de Ciências Sociais, 51: 313-352.

. (2008b). "Guerra cultural e transformaçôes sociais: as eleiçôes presidenciais de 2006 e a 'blogosfera' ". Sociedade e Estado, 23: 621-666.

Guilhot, N. (2006), Financiers, philanthropes: sociologie de Wall Street. Paris, Raisons d'Agir.

HeAP, SHAUN H. et al. (orgs.). (1992), Understanding the enterprise culture: themes in the work of Mary Douglas. Edinburgh, Edinburgh University Press.

Hirsch, P., Michaels, S. \& Friedman, Ray. (1990), "Clean models vs. dirty hands: Why economics is different from sociology”. In: DimagGio, S. Z. A. P. (org.), Structures of capital: the social organization of the economy. Nova York, Cambridge University Press, pp. 39-56.

Hirschman, A. O. (1986), Rival views of market society and other recent essays. Nova York, Viking.

JARDIM, M. A. C. (2007), Entre a solidariedade e o risco: sindicatos e fundos de pensão em tempos de governo Lula. Programa de Pós-Graduação em Ciências Sociais. Tese de doutorado. São Carlos, Universidade Federal de São Carlos.

Joseph, John \& OCASIO, William. (2005), "Cultural adaptation and institutional change: the evolution of vocabularies of corporate governance, 1972-2003”. Poetics, $33(3-4)$.

Labaton, S. (2002), "Bush tries to shrink S.E.C. raise intended for corporate cleanup”. New York Times, 19/10.

Lambe, G. (2007), "Cover story: Will private equity get you? A trickle of private equity activity in the financial institutions space is threatening to become a flood, with prime assets becoming targets". Geraldine Lambe Reports, NA. 
LAMUCCI, S. (2006), “Agenda liberal afugenta presidenciáveis”. Valor Econômico, 24/10.

Lerner, J. (2007), "Private equity under investigation: Justice Department doesn't understand how the industry works". HBS Alumni Bulletin, 83.

Leser, E. (2004), "Sean Harrigan est contraint de quitter la tête du fonds de pension américain Calpers". Le Monde, 03/12.

LORDON, F. (2000), Fonds de pension, piége à cons?: mirage de la démocratie actionnariale. Paris, Raisons d'Agir.

MacKenzie, D. A. (2006), An Engine, not a Camera: How financial models shape markets. Cambridge, Mass., MIT Press.

Martins, R. M. (2006), "Petros e a indústria de venture capital e private equity (diversificação e perspectiva de longo prazo)". III Ciclo de Debates - Venture Capital no Brasil. Rio de Janeiro, 27/04.

MarX, K. (1976), Le Capital: critique de l'économie politique 3, Le Procès d'ensemble de la production capitaliste. Paris, Ed. Sociales.

McAdam, D., McCARTHY, J. D. et al. (1996), Comparative perspectives on social movements: political opportunities, mobilizing structures, and cultural Framings. Cambridge/ Nova York, Cambridge University Press.

McCormick, P. (1996), Starmaking realism, anti-realism, and irrealism. Cambridge, Mass., MIT Press.

MCGERR, M. E. (2005), A fierce discontent: the rise and fall of the progressive movement in America, 1870-1920. Nova York, Oxford University Press.

Michael, A. (2003), "Ex-sindicalistas e apadrinhados ocupam CEF". Folha de S. Paulo, 29/09.

Michael, I. D. A. (2004), "Kroll tinha fortes ligações com a área policial, diz PF". Folha de S. Paulo, 04/08, A11.

MonTAGNE, S. (2006), Les fonds de pension entre protection sociale et spéculation financière. Paris, O. Jacob.

Murphy, P. (2002), "Esquerda e Bovespa fazem aliança estratégica. Para presidente da Bolsa, 'muro de Berlim caiu' com a inédita visita de Lula ao pregão". O Estado de S. Paulo, 01/09.

News, B. (2007), "Calpers invests $\$ 400$ Million in Pacific Corporate Group Unit". San Jose Mercury News, 08/06.

NikONOFF, J. (1999), La comédie des fonds de pension: une faillite intellectuelle. Paris, Arléa.

O Globo Online. (2006), “Debate: Aerolula e 'lógica da ética’ dominam quarto bloco", 08/10.

Palhano, A. (2007), "Novas oportunidades. Álcool, combustível (e investimento) do futuro. Por enquanto, o jogo está restrito ao clube dos milionários, mas o pequeno aplicador tem meios para não ficar de fora”. Folha de S. Paulo, 16/04. 
Pavini, A. (2007), “Mais risco, mais prazo”. O Estado de S. Paulo, 17/05.

POLANYI, K. (2001 [1944]), The great transformation: the political and economic origins of our time. Boston, MA, Beacon Press.

Poston, T. (2006), "A rollercoaster: The private equity industry has seen its share of highs and lows. They spent an estimated $£ 23$ bn in 2005 and employ three million people in the UK - yet few know much about them". BBC News Business Reporter, 09/01.

Revista Fundo de Pensāo. (2007), "Private equity: o novo ciclo de investimento em capital de risco", 326: 11-16.

Ribeiro, A. P. (2006), "Governo negocia queda de juros para empréstimo consignado". Folha de S. Paulo, 23/05.

Ribeiro, M. (2007), “CIE é vendida por US\$ 150 milhōes: Fernando Alterio e Gávea Investimentos, de Armínio Fraga, assumem controle da empresa mexicana de eventos". O Estado de S. Paulo, 09/05.

Ripardo, S. (2002a), "Bovespa faz 112 anos e enfrenta a pior crise da história”. Folha de S. Paulo, 20/08.

. (2002b), "Poucas corretoras independentes vão sobreviver, diz Booz Allen". Folha de S. Paulo, 20/08.

. (2002c), "Projeto Bovespa-Lula reedita propostas do plano diretor de abril". Folha Online, 01/10.

Rodrigues, F. (2006), "Lula se beneficia da situação de vítima, diz publicitário João Santana”. Folha de S. Paulo, 05/11.

Romero, C. (2007), "Fundos de pensão perdem força política”. Valor Econômico, 11/06.

Rosa, S. (2007), "Fundos se voltam para a bioenergia". DCI - Diário do Comércio, Indústria e Serviços, 08/02.

RosA, V. (2006), "Afago de Lula visaria a esfriar resistência do setor à reeleição". $O$ Estado de S. Paulo, 17/08.

SANTOS, C. (2007), "Previ tem nova estratégia para seu private equity". Valor Econômico, $18 / 06$.

SARDEnBerG, C. A. (2006), "O PSDB acabou”. O Globo, Rio de Janeiro, 01/11.

Scholz, C. \& ArrudA, R. (2006), "Escândalos vão minando república sindical”. $O$ Estado de S. Paulo, 21/09.

SChumpeter, J. A. (1991), The economics and sociology of capitalism. New Jersey, Princeton University Press.

Senado. (2005), Depoimento de Daniel Dantas à Comissão Parlamentar Mista de Inquérito sobre a compra de votos. Atas Taquigráficas. Brasil, 21/09.

SingER, P. (1988a), "Inflação e mercado como sistemas alternativos de regulação". Estudos Avançados, 2: 77-87. 
. (1988b), "Reflexões sobre a inflação, conflito distributivo e democracia". In: ReIs, F. W. \& O’Donnell, G. A democracia no Brasil: dilemas e perspectivas. São Paulo, Vértice.

Smith, P. (2007), "A PR offensive on the buy-out high-wire". The Financial Times, 26/01.

SoRKIN, Andrew R. (2007), "Private firms lure chief executives with top pay". The New York Times, 08/01.

Sorkin, Andrew R. \& Anderson, Jenny. (2007), "Bill is offered to increase tax on private equity". The New York Times, 23/06.

Sorkin, Andrew R. \& MerCed, Michael J. de la. (2007), "Blackstone rival plans own I.P.O.”. The New York Times, 22/06.

STelzer, I. M. (2007), "Billionaires for Obama. Can private equity funds survive a hostile political environment unscathed?". The Weekly Standard, 12 (35).

Sunstein, C. R. (2007), “A brave new Wikiworld”. Washington Post, 24/02.

The Economist. (1994), "Ready to take on the world”, 65-66, 15/01.

. (2004), "How private equity is changing the business world". 373: 10, 27/11.

. (2007a), "The buy-out business is booming, but capitalism's new kings are attracting growing criticism”, 382: 82, 10/02.

. (2007b), "Once bitten, twice shy; Private equity in Latin America. (It takes a long time for buy-out firms to forgive and forget)", 09/06.

Tноме́, C. (2007), "Aposentados terão crédito consignado para viajar: A ministra do Turismo, Marta Suplicy, calcula que os juros ficarão abaixo de 1\%”. O Estado de S. Paulo, $29 / 05$.

Thompson, P. (1997), "The pyrrhic victory of gentlemanly capitalism: the financial elite of the City of London, 1945-90". Journal of the Contemporary History, 32 (3): 283-304.

VALOR ECONOMico. (2001), “Terceira geração da família Ermírio de Moraes já comanda o Votorantim", 31/08.

. (2007), "Líder em chá pronto, Leão Júnior é alvo de bancos e multinacionais", $25 / 01$.

Veríssimo, L. (2007), "Bolsa deve agradecer o que o governo fez por ela, diz Lula: 'Agora ela está parecendo bolsa mesmo, porque tem volume. Não é aquela bolsa pequenininha, que parecia um enfeite', disse o presidente em discurso no BNDES”. O Estado de S. Paulo, 17/05.

Vieira, C. (2004), “Calpers deve investir em imóveis no Brasil”. Valor Econômico, São Paulo, 09/07. . (2007), "Aumenta o número de operações de empréstimo consignado em abril". A Voz do Brasil, 16/05. 
Walsh, M. W. (2002), "Calpers wears a party, or union, label”. The New York Times. Nova York, 13/10.

. (2004), "Calpers ouster puts focus on how funds wield power". The New York Times, Nova York, 02/12.

WARnER, J. (2007), “As KKR floats, are we at the market top?”, The Independent, 5/07. Williams, Karel \& Froud, Julie. (2007), "Private equity and the culture of value extraction”. CRESC Working Paper Series, n. 31, CRESC, The University of Manchester.

Zelizer, V. A. R. (1979), Morals and markets: the development of life insurance in the United States. Nova York, Columbia University Press.

Zilbovicius, M. \& Arbix, G. (1997), De JK a FHC: a reinvenção dos carros. São Paulo, Scritta.

\section{Resumo}

\section{Financeirização de esquerda? Frutos inesperados no Brasil do século XXI}

Diversos episódios e evoluçōes recentes mostram a adesão de setores tradicionais e novos das elites brasileiras ao predomínio das finanças e de suas razões na sociedade brasileira. A partir da análise do engendramento e da difusão da governança corporativa e dos fundos de private equities na acepção que elas vêm ganhando no Brasil, podemos mesmo falar de convergência das elites em torno dos mecanismos criados para a medição financeira, ainda que o resultado ocorra por meio de um alargamento de sua polissemia. Esses mecanismos, para cá trazidos no intuito explícito de acelerar e facilitar a integração das empresas brasileiras ao espaço e à lógica que impera nos mercados financeiros, avançam rapidamente, mas acabam recebendo um significado menos hardcore do que os financistas esperam. Ainda que deploráveis para os financistas ortodoxos, esses resultados dificilmente surpreenderiam um cientista social treinado. É por intermédio da polissemia que as abóboras se ajeitam na carroça da sociedade em movimento. A análise desse diálogo social produzido em torno das questôes financeiras se torna assim uma excelente janela para a compreensão não só das disputas econômicas, mas também das disputas políticas que sacodem a sociedade brasileira contemporânea.

Palavras-chave: Sociologia econômica; Estudos sociais sobre finanças; Governança corporativa; Private equity.

\section{Abstract}

\section{Leftist financialization? Unexpected outcomes in $21^{\text {st }}$ century Brazil}

Various recent episodes and evolutions demonstrate how both traditional and new sectors of the Brazilian elite have embraced the dominance of finance and its logic in 
Brazilian society. An analysis of the creation and diffusion of corporate governance and private equity funds - in the sense these have acquired in Brazil - allows us to identify a convergence of the country's elite sectors in terms of the mechanisms created for financial measurement, although this outcome stems from a broadening of their polysemy. Explicitly introduced into Brazil to accelerate and facilitate the integration of Brazilian companies in the space and prevailing logic of financial markets, these mechanisms are making rapid advances, but are given a less hardcore meaning than the kind expected by financial experts. Though deplorable for more orthodox financial specialists, such an outcome is unlikely to surprise a trained social scientist. It is through polysemy that, as the Brazilian saying goes, "the pumpkins sort themselves out on the cart" formed by a society continually in transit. Analysis of the social dialogue surrounding financial issues therefore provides an excellent window for comprehending not only the economic disputes but also the political disputes agitating contemporary Brazilian society.

Keywords: Economic sociology; Social studies of finance; Corporate governance; Private equity. 